\title{
Da história como ciência e como forma de rememoração: Construção salvadora e destruição redentora em Walter Benjamin*
}

\begin{abstract}
Amon Pinho ${ }^{1}$
Resumo

Refletir sobre a concepção benjaminiana da história como ciência e como forma de rememoração significa, antes de mais, pensar sobre a singular relação entre teologia e marxismo nela estabelecida. Relação, como veremos, de complementaridade dialética, por meio da qual Walter Benjamin articuladamente constituiu o cerne mesmo da sua teoria da história.
\end{abstract}

Palavras-chave: Walter Benjamin - conceito de história - teologia - marxismo - política.

\begin{abstract}
Reflecting upon the Benjaminian conception of history as a science and as a form of remembrance means, first of all, to think about the peculiar relationship it establishes between theology and Marxism. A relationship, as we shall see, of dialectical complementarity through which Walter Benjamin built the core of his theory of history.
\end{abstract}

Keywords: Walter Benjamin - concept of history - theology - Marxism - politics.

\footnotetext{
* Inédito no Brasil, e revisto para a presente publicação, este texto foi elaborado no âmbito do Projeto de Investigação "A Questão de Deus: História e Crítica", concebido e coordenado pela Prof. a Dr. ${ }^{\text {a }}$ Maria Leonor Xavier, e apoiado pelo Centro de Filosofia da Universidade de Lisboa (CFUL), bem como pela Fundação para a Ciência e a Tecnologia (FCT), do Ministério da Ciência, Tecnologia e Ensino Superior (MCTES) de Portugal.

${ }^{1}$ Centro de Filosofia da Universidade de Lisboa
} 
Ao reabrir hoje a questão do sagrado, a Filosofia não faz profissão de teísmo ou de antiteísmo. No entanto, na época do niilismo, que é a nossa - a época em que, para dizê-lo como Nietzsche, desvalorizam-se todos os valores, a partir da derrocada dos mais elevados -, é preciso que repensemos o sagrado e o divino. Esta a dolorosa alternativa de quem não é beneficiário da Fé. Benedito Nunes, Aspecto teológico da Filosofia.

"Sol, detém-te em Gabaon, e tu, lua, no vale de Aialon!" E o sol se deteve e a lua ficou imóvel (...). O sol ficou imóvel no meio do céu e atrasou o seu ocaso de quase um dia inteiro. Nunca houve dia semelhante, nem antes, nem depois, quando Iahweh obedeceu à voz de um homem. Livro de Josué, A Bíblia de Jerusalém.

Como flores que voltam suas corolas para o sol, assim o que foi [das Gewesene] aspira, por um secreto heliotropismo, a voltar-se para o sol que está a se levantar no céu da história. Essa mudança, a mais imperceptível de todas, o materialista histórico tem que saber discernir. Walter Benjamin, Sobre o conceito de história.

Memória é o Segredo da Redenção. Ba'al Shem Tov.

É objetivo do presente escrito enveredar por aquele que, a meu ver, tem sido um dos mais candentes aspectos do pensamento e da obra de Walter Benjamin, o filósofo, crítico literário e historiador da cultura judeu-alemão que, ao elaborar a sua concepção da história como ciência e como forma de rememoração (Eingedenken), realizou uma notável junção entre o materialismo histórico e a teologia e mística judaicas - às quais não deixou de articular também certas noções de extração cristã. Junção tão peculiar quanto paradoxal que está no cerne mesmo da sua teoria da história, que aqui pretendo abordar através de dois dos seus mais relevantes escritos.

Refiro-me, em primeiro lugar, às teses Sobre o conceito de história - redigidas meses antes da morte do autor, e não raro perspectivadas enquanto texto-síntese de todo o seu pensamento -, bem como às suas esclarecedoras notas preparatórias, em que nos deparamos com as reveladoras formulações das variantes e paralipômenos. E, em segundo lugar, ao inacabado trabalho das Passagens, cuja preparação deu-se inicialmente entre 1927 e 1929, e, posteriormente, do ano de 1934 ao de 1940, período em que foi retomado e desenvolvido, por aí dando corpo a um vasto e variegado conjunto de mais de 3500 fragmentos de notas e 
materiais - além de dois exposés e alguns esboços -, reunidos, classificados e distribuídos ao longo de quase quatro dezenas de arquivos temáticos (konvolute $)^{2}$.

Arquivos que se, por um lado, não são mais do que partes, em estado bruto ou gestacional, de uma obra que quedou inconclusa e fragmentária, por outro, e por isso mesmo, como que acabaram por se constituir numa espécie de Benjamin's working lexicon, para utilizarmos os termos de Susan Buck-Morss, isto é, num "dicionário de trabalho de suas idéias e investigações, ou mais precisamente, no depósito histórico de partes documentais e armações teóricas, com as quais construiu, durante a década de 1930, toda a ampla gama de suas obras literário-filosóficas",3, junto das quais - permitam-mo acrescentar -, bem poderíamos situar as próprias teses Sobre o conceito de história, não obstante redigidas já em inícios de 1940.

Afinal, não são nem aleatórias nem residuais, as similaridades e correspondências, quando não co-incidências, dos conteúdos apresentados nas Thesen, e, ou, nas respectivas notas preparatórias, com aqueles que surpreendemos em muitos dos fragmentos de "Teoria do conhecimento, teoria do progresso", o Arquivo N do livro das Passagens, conforme a nomenclatura classificatória criada por Benjamin, para designar as diversas instâncias daquela imensa oficina, a partir da qual intentava construir a sua obra máxima ${ }^{4}$.

Tomemos, a propósito, um desses fragmentos como mote introdutório de uma primeira e fundamental questão: a relativa ao estatuto da teologia no pensar de Walter Benjamin, e que no fragmento em causa explicita-se assim: "Meu pensamento está para a teologia como o mata-borrão está para a tinta: ele está completamente embebido dela. Mas se fosse pelo mata-borrão, nada restaria do que está escrito"5. Ou seja, se dependesse apenas

\footnotetext{
${ }^{2}$ Cf. BOLLE, Wille. "Nota introdutória". In: BENJAMIN, Walter. Passagens. Belo Horizonte: Editora UFMG; São Paulo: Imprensa Oficial do Estado de São Paulo, 2006, p. 71.

${ }^{3}$ BUCK-MORSS, Susan. Dialética do Olhar: Walter Benjamin e o Projeto das Passagens. Belo Horizonte: Editora UFMG; Chapecó, SC: Editora Universitária Argos, 2002, p. 251.

${ }^{4} \mathrm{O}$ tema desta obra são as passagens parisienses, "galerias de estrutura metálica, cobertas por tetos de vidro, construídas em geral entre 1790 e 1860. Elas reuniam muitas lojas e as pessoas passeavam por elas, olhando, fascinadas, as mercadorias expostas nas vitrinas, num clima de sonho, realçado pela iluminação a gás. Ele [Benjamin] achou que valia a pena escrever todo um livro a respeito do universo espiritual que se expressava nessas galerias, um estudo que contribuiria decisivamente para uma compreensão aprofundada não só da história da França, mas da história de toda a Europa no século XIX. Falou do projeto a [Gershom] Scholem e a [Theodor] Adorno [entre outros], adotou-o como referência essencial para empreender várias investigações". Cf. KONDER, Leandro. Walter Benjamin: o marxismo da melancolia. Rio de Janeiro: Campus, 1988, p. 45.

${ }^{5}$ A tradução para o português, tanto desta quanto das demais citações provenientes da obra das Passagens, foi fixada a partir da consulta a, e confrontação entre, as edições alemã (Das Passagen-Werk. In: Gesammelte
} 
do mata-borrão, ou, desfazendo-nos da metáfora, se dependesse apenas do pensamento benjaminiano, a tinta-teologia seria inteiramente absorvida, passando do exterior ao interior e do visível ao imediatamente invisível, uma vez que, além de assimilada, apropriada e desconstruída no seio daquele pensamento. Um pensamento, pois, impregnado de teologia, profundamente marcado e permeado por ela, mas que, ainda assim, nem por isso deixou de ser profano para tornar-se sagrado, antes tendo feito do sagrado uma força inspiradora, atuante e decisiva, para não dizer explosiva, a lampejar quando oportuno (kairós), lá, no cerne mesmo do pensamento profano.

Dito de outro modo, é indispensável ter-se claro que de teologia positiva, em Benjamin, só se encontrarão traços apagados. E apagados porque intimamente incorporados para além do seu último vestígio, na forma de uma "teologia negativa" ou "inversa", se bem lembramos os termos com que se lhe referiu Theodor Wiesengrund Adorno ${ }^{6}$. Termos, aliás, aos quais deveríamos juntar, ainda na tentativa de melhor aclararmos o estatuto do teológico em Benjamin, a preocupação de se demarcar nitidamente a figura da teologia dos fenômenos da religião e do religioso. Como salientou Jeanne-Marie Gagnebin, não obstante medularmente impregnado por aquela, o pensamento de Walter Benjamin manteve uma “distância crítica importante" relativamente a estes?.

E com efeito. Basta atentar-se - reportando-nos ao que aqui será de nosso especial interesse - para o caráter da função desempenhada pelas categorias teológicas, místicas e messiânicas, no âmbito da armação teórica da filosofia benjaminiana da história - a qual contém, outrossim, elementos materialistas e marxistas -, para se perceber que o "recurso

Schriften, v. V, t. 1 e 2. Frankfurt am Main: Suhrkamp, 1982), brasileira (Passagens, ed. cit.), francesa (Paris, Capitale du XIX Siècle: Le Livre des Passages. $3^{\mathrm{e}}$ ed. Paris: Les Éditions du Cerf, 2000), norte-americana (The Arcades Project. Cambridge, Massachusetts: The Belknap Press of Harvard University Press, 1999) e chilena (La Dialéctica en Suspenso: Fragmentos sobre historia. Santiago: Universidad ARCIS: LOM Ediciones, s.d. - que, das Passagens, inclui apenas o Arquivo N) e que, doravante, passarão a ser indicadas como Passagen, Passagens, Passages, Arcades e Pasajes, respectivamente, seguidas dos números das páginas. No caso do fragmento supra, e conforme a mesma sequência, estes são: 588, 513, 488, 471 e 140. Quanto aos Gesammelte Schriften de Benjamin, publicados ao longo de 7 volumes, entre os anos de 1972 e 1989, sob a organização geral de Rolf Tiedemann e Hermann Schweppenhäuser, as referências serão sempre feitas como $G S$, seguido da indicação dos números do volume, do tomo e da página.

${ }^{6}$ Cf. BOLZ, Norbert W. "É preciso teologia para pensar o fim da história? Filosofia da história em Walter Benjamin”. Revista USP (Dossiê Walter Benjamin), São Paulo, n. ${ }^{\circ} 15,1992$, p. 26. Ver também BUCKMORSS, op. cit., p. 294.

7 GAGNEBIN, Jeanne-Marie. "Teologia e messianismo no pensamento de Walter Benjamin". Estudos Avançados, São Paulo, v. 13, no. 37, set./dez., 1999, p. 196. 
teórico à teologia não é (...) sinônimo de invocação à religião", filosófica, recurso epistemológico e político. E que, portanto, não diz diretamente respeito aos assuntos da fé.

Como, adiante, teremos oportunidade de verificar, noções como as de salvação (Rettung), redenção (Erlösung), Messias, Anticristo, inferno e Juízo Final, distinguir-se-ão não pelo seu sentido religioso original, mas pela intenção materialista que lhes é atribuída, com o fito de deslocá-los do campo da religião para a esfera secular do conhecimento histórico-filosófico e da política.

Donde, na linha argumentativa de Michael Löwy, a incontornável constatação de que, para Benjamin, a teologia não constitui "um objetivo em si, não visa à contemplação inefável de verdades eternas, e muito menos, como poderia a etimologia levar a crer, à reflexão sobre a natureza do Ser divino". "Não há um Messias enviado do céu: somos nós o Messias". "Deus está ausente, e a tarefa messiânica é inteiramente atribuída às gerações humanas. O único Messias possível é coletivo: é a própria humanidade, mais precisamente, (...) a humanidade oprimida. Não se trata de esperar o Messias, ou de calcular o dia de sua chegada - como o fazem os cabalistas e outros místicos judeus que praticam a gematria mas de agir coletivamente. A redenção é [pois] uma auto-redenção"9.

Documento imprescindível tanto para a formulação dessas considerações de Löwy, quanto para uma compreensão mais completa e mediada de aspectos centrais do conjunto da obra de Walter Benjamin - não confessou ele ter ali exposto pensamentos que guardava para si, e mesmo de si, há cerca de vinte anos? - as teses Sobre o conceito de história apresentam, logo à entrada, uma alegoria que, a despeito de toda a controvérsia gerada no calor da sua recepção, me parece aclaradora quer da questão do estatuto da teologia quer da especificidade do tipo de junção, que nela se propõe, entre o materialismo histórico e aquela.

"Como se sabe [escreve Benjamin], deve ter havido um autômato, construído de tal maneira que, a cada jogada de um enxadrista, ele respondia com uma contrajogada que lhe assegurava a vitória da partida. Diante do tabuleiro, que repousava sobre uma ampla mesa, sentava-se um boneco em trajes turcos, com um narguilé à boca. Um sistema de espelhos despertava a ilusão de que essa mesa de todos os lados era transparente. Na

${ }^{8}$ GAGNEBIN, Jeanne-Marie. História e Narração em Walter Benjamin. $2^{\mathrm{a}}$ ed. São Paulo: Perspectiva, 1999, p. 22.

${ }^{9}$ LÖWY, Michael. Walter Benjamin: aviso de incêndio: uma leitura das teses "Sobre o conceito de história". São Paulo: Boitempo, 2005, pp. 45, 51 e 52. Observo, quanto aos grifos existentes nas citações, que sempre que nada em contrário for assinalado, devem ser eles atribuídos ao próprio autor ou autora em questão. 
verdade, um anão corcunda, mestre no jogo de xadrez, estava sentado dentro dela e conduzia, por fios, a mão do boneco. Pode-se imaginar na filosofia uma contrapartida dessa aparelhagem. O boneco chamado 'materialismo histórico' deve ganhar sempre. Ele pode medir-se, sem mais, com qualquer adversário, desde que tome a seu serviço a teologia, que, hoje, sabidamente, é pequena e feia e que, de toda maneira, não deve se deixar ver" ${ }^{\prime 10}$.

Começando pelo fim, e limitando-me a comentar apenas o que, consoante a clivagem deste meu escrito, se me afigura essencial, chamo a atenção, primeiramente, para a imagem atribuída à teologia no quadro da alegoria. Identificada com o anão corcunda, mestre no jogo de xadrez, ela não deve se deixar ver, permanecendo na parte interna do que seria a contrapartida filosófica da tal aparelhagem ${ }^{11}$. Numa época incrédula e racionalista, marcada pela "morte de Deus" (Nietzsche) e pelo "desencantamento do mundo" (Weber), a teologia é enfeada e empequenecida, torna-se uma "velha enrugada e mal-afamada" - no dizer da tradução francesa realizada pelo próprio Benjamin ${ }^{12}$-, tendo por isso que se manter escondida, não aparente, imediatamente invisível, latente, lá, “onde ninguém dela suspeitará"13, ainda que seja o spiritus rector (o espírito dirigente, ou guia, ou regente) do boneco denominado "materialismo histórico". Deste, por sua vez, embora representado pelo boneco que o anão vivifica, conduzindo-lhe os movimentos e assegurando-lhe a vitória, é dito que ganhará sempre, desde que tome a teologia a seu serviço, isto é, desde que, invertendo a célebre fórmula escolástica da filosofia como serva da teologia (ancilla theologiae), converta a teologia em serva da filosofia (ancilla philosophiae).

\footnotetext{
${ }^{10}$ BENJAMIN, Walter. "Sobre o conceito de história" [a partir daqui: Teses, seguido do número da página]. In: LÖWY, op. cit., p. 41. Cf. GS, I-2, p. 693. Entre as traduções das teses, desde o original alemão, para o português existentes, optamos por esta que acompanha o livro referido de Michael Löwy. Da autoria de Jeanne-Marie Gagnebin e Marcos Lutz Müller, e apreciada por Löwy como a "melhor e mais apurada" (p. 38), ela distingui-se pelo importante critério da literalidade. Menos literal, mas também excelente, é a tradução de Sérgio Paulo Rouanet em BENJAMIN, Walter. Magia e Técnica, Arte e Política: Ensaios sobre literatura e história da cultura. São Paulo: Brasiliense, 1985, pp. 222-232. Vide igualmente, posto que experiência sempre interessante, a tradução para o francês que Benjamin, ele-mesmo, fez de boa parte das teses, exceção feita às de número VIII, XI, XIII, XIV, XVI, mais os apêndices A e B, em GS, I-3, pp. 12601266. Não se trata de uma translação ipsis litteris, pois ao efetuá-la, o autor introduziu uma série de alterações em diversas passagens do texto. O que, por sinal, aos olhos da exegese, o torna ainda mais estimulante.

${ }^{11}$ Curioso notar que, ao escrever as teses, Benjamin parece não ter levado em conta tal orientação. Afinal, ali, a teologia figura visível. "Talvez seja um conselho aos leitores do documento [especula Löwy]: utilizem a teologia, mas não a mostrem. Ou então, como o texto [originalmente] não estava destinado à publicação [veio a lume postumamente], não era necessário esconder o anão corcunda dos olhos do público". LÖWY, op. cit., p. 44.

${ }_{12} G S$, I-3, p. 1260.

${ }^{13}$ Id., ibid., p. 1260.
} 
Do que se pode concluir que, para Benjamin, teologia e filosofia, messianismo e materialismo, cabalismo e marxismo, um deveria se constituir a partir do outro, um deveria se definir pelo outro, numa relação de exclusão recíproca (um seria o que o outro não fosse: quando um fosse servo o outro seria mestre e quando um fosse mestre o outro seria servo) e de inclusão simétrica (ambos seriam servo e mestre ao mesmo tempo), quero dizer, numa relação de complementaridade dialética, regida por um Benjamin ora teólogo, ora marxista, sempre marxista e teólogo.

"É verdade [pondera percucientemente Löwy] que essas duas concepções são habitualmente contraditórias, mas o autor das teses não é um pensador 'habitual': ele as reinterpreta, transforma e situa numa relação de esclarecimento recíproco que permite articulá-las de forma coerente. Ele gostava de se comparar a Janus, que com uma das faces olha para Moscou e com a outra para Jerusalém. Mas se esquece freqüentemente de que o deus romano tinha duas faces mas uma única cabeça: marxismo e messianismo são apenas duas expressões (...) de um único pensamento. Um pensamento inovador, original, inclassificável, que se caracteriza pelo que ele chama (...) de 'paradoxal reversibilidade recíproca' (...) do político no religioso [leia-se: teológico] e vice-versa. Para melhor apreender a relação complexa e sutil entre redenção e revolução em sua filosofia da história, seria necessário falar de afinidade eletiva, ou seja, de atração mútua e reforço recíproco das duas condutas, a partir de algumas analogias estruturais, desembocando em uma espécie de fusão alquímica" ${ }^{\text {"14. }}$.

Discutidos, grosso modo, quer o estatuto da teologia, quer o caráter da associação entre esta e o materialismo referido, passemos, agora, a uma consideração mais detida do conceito benjaminiano de história ${ }^{15}$, ou, se dito de outra forma, da teoria da história egressa do movimento de um pensamento que a si se reconhecia na simbólica da imagem de um deus bifronte, cujas faces, alquimicamente fundidas, miravam adversários teórico-políticos a enfrentar. Daí as teses constituírem, segundo as palavras de Benjamin numa carta a Max Horkheimer, "uma primeira tentativa de fixar um aspecto da história que deve estabelecer uma cisão irremediável entre nossa forma de ver e as sobrevivências do positivismo"16. Sobrevivências estas que permeavam o historicismo, o marxismo evolucionista vulgar da

\footnotetext{
${ }^{14}$ LÖWY, op. cit., pp. 36-37. Entre outros estudos da autoria de Michael Löwy, veja-se também Redenção e Utopia: O judaísmo libertário na Europa Central (um estudo de afinidade eletiva). São Paulo: Companhia das Letras, 1989, em particular o capítulo 6: "Distante de todas as correntes e no cruzamento dos caminhos: Walter Benjamin".

${ }^{15}$ Em conformidade com a anfibologia do seu sentido, o termo "história" é aqui perspectivado na sua dupla acepção de res gestae, coisas sucedidas, e de historia rerum gestarum, relação ou narrativa das coisas sucedidas.

${ }^{16} G S, \mathrm{I}-3$, p. 1225.
} 
socialdemocracia e a ortodoxia marxista soviética, três correntes contra as quais a idéia benjaminiana de história se vai voltar.

Centremo-nos, quanto a este triplo dissenso, apenas nas críticas endereçadas ao historicismo, caracterizado nas Passagens como "o mais poderoso narcótico do século"17. E se assim o era, tratava-se, pois, de, semelhantemente ao método de fissão dos átomos, liberar as enormes forças históricas que, entorpecidas, permaneciam prisioneiras do "era uma vez" da historiografia tradicional, bem como do seu voto de neutralidade pretensamente científica de reviver o passado "tal como efetivamente aconteceu", consoante a renomada frase de Leopold von Ranke.

O método típico do adepto do historicismo é o da empatia ou identificação afetiva (Einfühlung, "sentir-se em"), um caminho direto, sem desvios ou mediações. Para compreender a humanidade pretérita tal como esta se compreendia, ele esforça-se em identificar-se com ela. Despoja-se de si para pensá-la e senti-la tal como realmente foi, para fazer sua a experiência vivida (Erlebnis) dela. Está seguro de que tem condições de espelhá-la puramente, na medida em que "se esqueceu" das particularidades que lhe são intrínsecas e das especificidades do seu tempo presente. Ele não toma o desvio crítico do questionamento dos próprios pré-conceitos (Vorurteil), nem das determinações peculiares à própria época. Mas isto não basta. Dedica-se, ainda, a isolar todo o conhecimento que detém acerca do que se passou entre o período histórico em investigação e os dias da atualidade em que bate o seu coração tristonho. "Si vous voulez revivre une époque, oubliez que vous savez ce qui s'est passé après elle”, ensinava o historicista francês Fustel de Coulanges. Eis "a magna charta secreta da apresentação [Darstellung] da história própria da escola histórica”, declarava Walter Benjamin ${ }^{18}$. E, ainda referindo-se ao ensinamento de Coulanges, acrescentava:

"Não se poderia caracterizar melhor o procedimento com o qual o materialismo histórico rompeu. É um procedimento de identificação afetiva. Sua origem é a indolência do coração, a acedia, que hesita em apoderarse da imagem histórica autêntica que lampeja fugaz. Para os teólogos da Idade Média ela contava como o fundamento originário da tristeza. (...) A natureza dessa tristeza torna-se mais nítida quando se levanta a questão de saber com quem, afinal, propriamente o historiador do Historicismo se identifica afetivamente. A resposta é, inegavelmente: com o vencedor. Ora, os dominantes de turno são os herdeiros de todos os que,

\footnotetext{
${ }^{17}$ Passagen, GS, V-1, p. 578; Passages, p. 480 ; Arcades, p. 463.
}

${ }^{18}$ Passagens, p. 514. Cf. Passagen, GS, V-1, p. 590. 
algum dia, venceram. A identificação afetiva com o vencedor ocorre, portanto, sempre, em proveito dos vencedores de turno. Isso diz o suficiente para o materialismo histórico"19.

E, simultaneamente, nos diz a nós o quanto a contundente crítica de Benjamin ao historicismo é, a um tempo, teórica e política; e, assim sendo, completa e conseqüente. Como é sabido, a historiografia dos grandes personagens e acontecimentos, típica dos prosélitos da escola histórica, além de ter materializado os limites estreitos da concepção de história então professada, deixou às claras as inclinações ideológicas nada neutras daqueles historiadores. Em França, por exemplo, as contradições entre o ideal historicista de perfeita imparcialidade científica e o seu desdobramento historiográfico efetivo eram desconcertantes.

"Os manuais escolares, sobretudo, diretamente inspirados pelos notáveis [professores] universitários, não hesitam em fazer o elogio da Terceira República, para alargar ao futuro a sua clientela eleitoral, portanto reforçar a sua base social; excitam permanentemente o sentimento patriótico, celebrando o culto dos heróis nacionais a fim de preparar a nova geração para a vingança contra o inimigo hereditário, o Bárbaro germânico; e justificam, a coberto de uma missão civilizadora, a expansão colonial da França. Nestas condições, a ciência histórica, que pretende a imparcialidade, a objetividade, revela-se um discurso ideológico que serve os interesses de um regime político ou manifesta as aspirações de uma comunidade nacional”20.

Alinhado aos interesses das classes dirigentes, no presente, e revivendo, por empatia, os vultosos personagens e eventos que predominaram no passado, o historicismo expressava o pensamento histórico conformado à situação; noutros termos, historiografia burguesa.

$\mathrm{Na}$ contra-mão dessa tendência, Walter Benjamin considera que a tarefa do materialista histórico é "escovar a história a contrapelo"21. Não é o exame filológico do que apenas consta na documentação oficial (o tipo de fonte privilegiada pela escola histórica), nem a história épica daqueles que foram vitoriosos e impuseram a sua versão dos fatos, o que deveria dar a medida das possibilidades do conhecimento histórico. Tratava-se, antes, de recuperar, em meio à multiplicidade diversificada de testemunhos do passado, aqueles que encerravam registros de idéias, sentimentos, anseios, aspirações, desejos, projetos,

\footnotetext{
${ }^{19}$ Teses, p. 70. Cf. GS, I-2, p. 696.

${ }^{20}$ BOURDÉ, Guy \& MARTIN, Hervé. As Escolas Históricas. Mem Martins, Portugal: Publicações EuropaAmérica, 1990, p. 115.

${ }^{21}$ Teses, p. 70. Cf. GS, I-2, p. 697.
} 
promessas e sonhos sociais que não chegaram a se concretizar ou que, em se concretizando, não constituíram realidades objetivas duradouras. Não por inaptidão ou fraqueza, mas porque no jogo de interesses, disputas e confrontos quase sempre assimétricos que se desenrolam na história, quem tem força se impõe. Embora a história da humanidade não seja inteiramente redutível à história da dominação, no sentido forte do termo, não foi sem acerto que Marx definiu a primeira pela segunda. Pois, com efeito, aos horrores bárbaros da escravidão e da servidão, seguiu-se o que ainda impera, o contemporâneo horror civilizado do sobretrabalho ${ }^{22}$.

O escovar a história a contrapelo significa a adoção de uma visada teórico-política voltada para o que não se estabeleceu historicamente, tendo com o passar do tempo sido abandonado, esquecido e sepultado debaixo dos desenvolvimentos históricos socialmente hegemônicos. O passado comportava outros futuros além do que realmente se efetivou, conformando o nosso presente. A tarefa da crítica materialista é arrebatar dos domínios do esquecimento tudo o que "teria podido fazer de nossa história uma outra história"; tudo o que, sendo futuro do pretérito, poderia ter se constituído em futuro do passado ${ }^{23}$. Se o que prevaleceu foi a sociedade de classes do capital e do trabalho, isto certamente não se deu nem por necessidade histórica, nem por falta de iniciativas individuais e coletivas decididas a fundar formas de organização social radicalmente distintas. A história de sangue e fogo dos movimentos de emancipação social, em suas vertentes milenarista, anarquista, socialista e comunista é prova disso.

No rastro de sua consolidação e permanência, a moderna sociedade burguesa produziu uma quantidade inimaginável de mercadorias, mas, em simultâneo, gerou um volume ainda maior de ruínas, destroços e estilhaços. Enganam-se aqueles que, sob o capitalismo, pensam haver paz sempre que não haja guerra . As conflagrações bélicas - que no século XX devastaram nações inteiras, com seu espírito criminoso de desgraça, destruição, horror e morticínio -, configuram "apenas" a fase aguda de uma luta diária pela dominação e organização econômica do mundo ${ }^{24}$, que se desenrola incessantemente na arena sem perdão da concorrência intercapitalista, esfera da produção efetiva do capital social global. Na

\footnotetext{
${ }^{22}$ MARX, Karl. O Capital: Crítica da Economia Política. Livro Primeiro: O processo de produção do capital, v. I, t. 1. $3^{\text {a }}$ ed. São Paulo: Nova Cultural, 1988, p. 182.

${ }^{23}$ GAGNEBIN, Jeanne-Marie. Walter Benjamin: os cacos da história. $2^{\mathrm{a}}$ ed. São Paulo: Brasiliense, 1993, pp. 52 e 61.

${ }^{24}$ SILVA, Agostinho da. Dispersos. $2^{\text {a }}$ ed. Lisboa: Icalp: Ministério da Educação, 1989, p. 198.
} 
forma capitalista de produção, processa-se um conflito surdo e contraditório que, periodicamente, vem à tona na forma agravada das crises, para que a sociedade civil, em continência econômico-social e, ou, militar, obedeça, com disciplina de caserna, às evoluções em marcha do movimento reprodutivo do capital.

“(...) a guerra é desenvolvida antes que a paz: [mostrar] como certas relações econômicas, tais como o trabalho assalariado, a máquina, etc., se desenvolveram mais cedo com a guerra e com os exércitos, do que no seio da sociedade burguesa" ${ }^{25}$.

Vidas ceifadas e realizações truncadas apelam por nós sob os escombros gerados pelo capitalismo. Escovar a história a contrapelo é cravar a pá nestes destroços para, em seguida, arremessá-los com vontade, violência, força e presença de espírito. A tarefa a cumprir é a de uma arqueologia radicalmente crítica da modernidade, cujo leitmotiv é o ofício da salvação e a prática da crítica redentora.

“O passado leva consigo um índice secreto pelo qual ele é remetido à redenção. Não nos afaga, pois, levemente um sopro de ar que envolveu os que nos precederam? Não ressoa nas vozes a que damos ouvido um eco das que estão, agora, caladas? E as mulheres que cortejamos não têm irmãs que jamais conheceram? Se assim é, um encontro secreto está então marcado entre as gerações passadas e a nossa. Então fomos esperados sobre a terra. Então nos foi dada, assim como a cada geração que nos procedeu, uma fraca força messiânica, à qual o passado tem pretensão. Essa pretensão não pode ser descartada sem custo. O materialista histórico sabe disso" $" 26$.

Ele está ciente de que a função do verdadeiro historiador é ler o que jamais foi escrito: o livro da vida dos homens e mulheres de outrora, de cuja memória ainda não se fez

\footnotetext{
${ }^{25}$ MARX, Karl. Manuscritos Econômico-Filosóficos e outros textos escolhidos. $2^{\text {a }}$ ed. São Paulo: Abril Cultural, 1978, p. 123. É em razão desse caráter determinante das sociedades capitalistas - caráter essencialmente conflituoso e antagônico -, que também encontramos, na crítica de Marx à economia política, expressões normalmente correntes em quartéis e em contextos de conflagração bélica. Se no seio da Grande Indústria, com seus "soldados rasos" (operários) e "suboficiais" (supervisores), o que ocorre é uma "batalha industrial", na qual os primeiros, submetidos a uma "disciplina de caserna", correm perigo de vida, na "arena" da esfera da concorrência intercapitalista, um agente do capital elimina o outro na "luta" concorrencial pelo "despojo coletivo" ou lucro, forma fetichizada da mais-valia, quer dizer, do excedente obtido com a exploração do trabalhador assalariado pelo capitalista. MARX, Karl. O Capital: Crítica da Economia Política. Livro Primeiro: O processo de produção do capital, v. I, t. 2. São Paulo: Abril Cultural, 1984, pp. 44-45; e MARX, Karl. O Capital: Crítica da Economia Política. Livro Terceiro: O processo global da produção capitalista, v. III, t. 1. São Paulo: Abril Cultural, 1984, pp. 172 e 191.

${ }^{26}$ Teses, p. 48. Cf. GS, I-2, pp. 693-694.
} 
história $^{27}$. Homens e mulheres emudecidos, soterrados pelo amontoado de ruínas em que se transformaram as construções inacabadas de suas respectivas trajetórias. Eles dirigem um chamado aos que estão no meio-dia dos tempos, os sujeitos históricos do agora. Querem ser recordados em sua existência difícil e malograda. Desejam ver as suas esperanças preenchidas e os sonhos sociais de uma sociedade outra realizados. Reivindicam lembrança e libertação, verdade e justiça. "Pois o Messias não vem somente como redentor [Erlöser]; ele vem como vencedor do Anticristo" 28 .

Cabe ao historiador materialista dinamitar a continuidade reificada da história, arrancando das entranhas desta as realidades históricas descontínuas que a falsa aparência dela esconde. Na forma de organização social em que o capital se apoderou do trabalho, sob a circulação cintilante e sedutora de mercadorias sempre esteve o caráter exploratório da produção, sob a igualdade jurídica, a desigualdade econômico-social, sob a identidade da forma, a diferença do conteúdo, sob a representação ilusória de um progresso sem precedentes da humanidade, a descontinuidade real produzida pelos antagonismos sociais dos cotidianos passado e presente. "Um inferno se enfurece [tobt] na alma da mercadoria, por mais que pareça que ela tenha encontrado no preço a sua paz"29.

Trata-se, portanto, de primeiramente arrancar dos territórios recobertos do esquecimento as demandas não cumpridas porque interditadas, as existências descontínuas da história, registrando-as e recordando-as enquanto historiografia; e de, em segundo lugar, contribuir para que tais demandas venham a se cumprir, saltando da dimensão da escrita para o calor da luta política. "Uma tal apresentação da história tem como meta, para falar como Engels, "sair do domínio do pensamento",30.

A salvação (Rettung) do passado tem, assim, um duplo aspecto: o do resgate historiográfico da memória dos atores emudecidos da história, e o do embate político pela plena efetivação das suas possibilidades e aspirações interrompidas. Logo, o materialista histórico não só reativa uma parte perdida do passado, recuperando e conservando o fio de uma história inacabada, ele também co-labora para que, no seu próprio presente, a

\footnotetext{
${ }^{27}$ Cf. BENJAMIN, Walter. "Paralipomènes et variantes des Thèses Sur le concept d'histoire". In: Écrits Français. Paris: Gallimard, 1991, p. 354; BENJAMIN, Walter. "Apuntes sobre el concepto de historia". In:___. La Dialéctica en Suspenso, p. 86; GS, I-3, p. 1238.

${ }^{28}$ Teses, p. 65. Cf. GS, I-2, p. 695.

${ }^{29}$ Cf. Passagens, p. 414; Passagen, GS, V-1, p. 466.

${ }^{30}$ Cf. Passagens, p. 517; Pasajes, 150 ; Passages, p. 493; Arcades, p. 475; Passagen, GS, V-1, p. 595.
} 
continuação dela seja tecida ${ }^{31}$. Esta continuação é atualização. Uma atualização redentora, que redime o passado na medida em que contribui para a transformação ativa do presente, no sentido da concretização de todos aqueles ideais, quereres, projetos, expectativas e sonhos sociais pretéritos malogrados: aqueles possíveis que poderiam ter acontecido mas não aconteceram, ou que chegaram a se expressar factualmente, mas não duradouramente. Foram vencidos pelos interesses que predominaram ou em tempos pré-capitalistas ou na sociedade do trabalho assalariado e do capital, este deus poderoso que permanece dando provas de sua força e "para o qual todos os sacrifícios serão sempre insuficientes"32.

Por mais surpreendente, estranho ou enigmático que num primeiro momento possa parecer, foi exatamente nas teologias judaica e cristã e na mística judaica, especialmente na Cabala, que Benjamin encontrou subsídio e inspiração para formular esta concepção epistemológico-política de que "também o passado quer ser resgatado, que ele aspira à sua reparação, que sua história não está terminada, e que se nos impõe, hoje, continuá-la"33. Como vimos, ainda que na condição de agentes secretos do seu pensamento, teologia e mística aí ocupam uma posição central. Centralidade, de resto, que pode ser aferida pela expressiva intensidade das controvérsias geradas em torno de ambas, no espaço dos estudos benjaminianos.

Para nós, a sua importância e significatividade é tanto mais cortante quanto mais nos damos conta das possibilidades extraordinárias do afiado fio da sua espada de fogo - fio heurístico, fio teórico, fio político -, neste mundo em que a profundidade das cosmovisões seculares dos povos foi reduzida ao fetiche da forma mercadoria, à "quintessência da falsa consciência", à "aparência da repetição do sempre-igual"34. Referimo-nos, por exemplo, e

\footnotetext{
${ }^{31}$ GAGNEBIN, Jeanne-Marie. Walter Benjamin: os cacos da história, p. 61.

${ }^{32}$ GRESPAN, Jorge Luis da Silva. O Negativo do Capital: O conceito de crise na crítica de Marx à economia política. São Paulo: Hucitec: Fapesp, 1998, p. 125.

${ }_{33}$ GAGNEBIN, Jeanne-Marie. Walter Benjamin: os cacos da história, pp. 70-71.

${ }^{34}$ Passagens, p. 48. Cf. Passagen, GS, V-1, p. 55. Os dois pequenos excertos acima citados foram extraídos de "Paris, a Capital do Século XIX", texto redigido por Benjamin, em 1935, como uma apresentação sumária do conjunto do trabalho das Passagens, tal como desenvolvido até a altura. Em carta a seu grande amigo Gershom Scholem - estudioso pioneiro e indispensável para quem se aventura nos campos luminosos da tradição mística judaica, e cujas pesquisas e perspectivas sobre a Cabala influenciaram profundamente Walter Benjamin -, relata que "ao fazer esse exposé (...), meu trabalho entrou num novo estádio, aliás, o primeiro que vagamente se aproxima de um livro. (...) desapareceu o título 'Pariser Passagen' ['Passagens Parisienses'] e o esboço chama-se 'Paris, die Hauptstadt des neunzehnten Jahrhunderts' ['Paris, a Capital do Século XIX'], e cá comigo intitulo-o 'Paris, capitale du XIX siècle'”. BENJAMIN, Walter \& SCHOLEM, Gershom. Correspondência. São Paulo: Perspectiva, 1993, pp. 218-219. Cf. Passagen, GS, V-2, pp. 1112 e 1113.
} 
axialmente, à possibilidade epistemologicamente fecunda e politicamente explosiva de alicerçar-se a concepção do tempo sobre a imagem da redenção (Bild der Erlösung):

"Na representação [Vorstellung] da felicidade (...) vibra conjuntamente a representação da redenção. Esta felicidade está fundada precisamente no desconsolo e no abandono que eram nossos. Nossa vida é, em outras palavras, um músculo que tem força suficiente para contrair todo o tempo histórico. Ou ainda, a autêntica concepção do tempo histórico repousa inteiramente na imagem da redenção"35.

E noutro fragmento do trabalho das Passagens, considera-se que:

“(...) a história não é somente uma ciência, mas tanto quanto uma forma de rememoração. O que a ciência 'estabeleceu', a rememoração pode modificar. A rememoração pode transformar o inacabado (a felicidade) em algo acabado, e o acabado (o sofrimento) em algo inacabado. Isto é teologia; na rememoração, porém, fazemos uma experiência que nos proíbe de conceber a história como fundamentalmente ateológica, embora tampouco nos seja permitido tentar escrevê-la com conceitos imediatamente teológicos"36.

Se a rememoração (Eingedenken) é "uma experiência (Erfahrung) que nos proíbe de conceber a história como fundamentalmente ateológica", pode-se inferir que é ela uma experiência teologicamente determinada. É seu atributo poder transformar a felicidade inacabada ou inconsumada em algo acabado ou consumado, e o acabamento do sofrimento em algo inacabado. Ou seja, a rememoração histórica constitui-se numa experiência potencialmente redentora, capaz de reparar o sofrimento e consumar a felicidade.

Sendo então a história, para Benjamin, simultaneamente ciência e forma de rememoração, compreende-se, agora, o fundamento teológico de por que cabe ao conhecimento histórico não apenas constatar objetivamente os conteúdos de determinados fatos e processos sociais pretéritos, com seus sofrimentos acabados e suas felicidades inacabadas; cabe igualmente a ele proceder à rememoração e mobilização desses conteúdos em função de uma necessidade de modificação radical do presente, no sentido de mandar pelos ares a ordem sócio-político-econômica que perpetua o acabamento do sofrimento e o inacabamento da felicidade. A história deve ser salvação, conservação e preservação dos aspectos soterrados do passado e, tanto quanto, redenção do passado e do presente pela dissolução e destruição de tudo o que, ainda gerando sofrimento, impede a concretização do

\footnotetext{
${ }^{35}$ Cf. Pasajes, p. 158; Passages, pp. 497-498; Passagen, GS, V-1, p. 600; Passagens, p. 521; Arcades, p. 479. ${ }^{36}$ Cf. Passages, p. 489; Passagens, p. 513; Pasajes, p. 141; Passagen, GS, V-1, p. 589; Arcades, p. 471. Grifo meu.
} 
potencial irrealizado da felicidade $\operatorname{social}^{37}$. "A apresentação materialista da história leva o passado a colocar o presente numa situação crítica"38. Sua "construção pressupõe destruição" 39 .

Por conceber a história não apenas como ciência, mas também como forma de rememoração, a teoria benjaminiana da história não pode ser indiscriminadamente apropriada. Ela só é aplicável aos estudos históricos que se ocupam dos aspectos do passado que apresentam um certo grau de atualidade. Segundo Benjamin, o historiador tem que edificar uma estrutura filosófica delgada mas sólida, para apanhar, em sua rede, os mais atuais aspectos do passado ${ }^{40}$. Isto é, os aspectos do passado que nos são lembrados pelo devir dos acontecimentos presentes, em razão das correspondências ou semelhanças que apresentam entre si. Em seu vir a ser, os acontecimentos presentes, com maior ou menor grau de explicitação, como que citam os acontecimentos passados que lhes são semelhantes. Mas perceber essas citações, nem sempre evidentes, do semelhante é algo que depende da qualidade da atenção e do grau de conhecimento do intérprete. Pois, verdade seja dita, o presente a todo o momento cita o passado. Deste, ele se encontra repleno e no seu desdobrarse precipitam-se séculos ${ }^{41}$.

\footnotetext{
${ }^{37}$ Numa esclarecedora consideração sobre as noções de redenção e salvação, na concresção teórica da concepção benjaminiana da história, Jeanne-Marie Gagnebin observa que "os termos Erlösung, erlösen, Erlöser remetem ao radical lös (no grego antigo luein, livrar ou desatar...), indicam a dissolução, o desfecho, a resolução ou solução de um problema, por exemplo, por seu desaparecimento bem-vindo. A redenção (Erlösung), em Benjamin, não se confunde, portanto, (...) com a idéia, tão importante, de uma salvação ou conservação (Rettung) do passado pelo trabalho necessário do historiador e a prática da rememoração (Eingedenken). Se a redenção livra é porque ela destrói e dissolve, não porque mantém e conserva". GAGNEBIN, Jeanne-Marie. "Teologia e messianismo no pensamento de Walter Benjamin". Estudos Avançados, p. 198.

${ }^{38}$ Passagens, p. 513. Cf. Pasajes, p. 140; Passages, p. 488; Arcades, p. 471; Passagen, GS, V-1, p. 588.

${ }^{39}$ Passagens, p. 512; Arcades, p. 470; Passagen, GS, V-1, p. 587.

${ }^{40}$ Cf. Passages, p. 475; Pasajes, p. 123; Passagens, p. 501; Arcades, p. 459; Passagen, GS, V-1, p. 572.

${ }^{41}$ Significativamente, já na primeira frase do primeiro capítulo do seu livro Era dos Extremos: o breve século XX (1914-1991), o historiador inglês Eric Hobsbawm fornece um interessante exemplo para a questão que acabamos de tratar. Relata ele que "Em 28 de junho de 1992 o presidente Mitterrand, da França, apareceu de forma súbita, não anunciada e inesperada em Sarajevo, que já era o centro de uma guerra balcânica que iria custar cerca de 150 mil vidas no decorrer daquele ano. Seu objetivo era lembrar à opinião pública mundial a gravidade da crise bósnia. E, de fato, foi muito observada e admirada a presença do conhecido estadista idoso e visivelmente frágil sob o fogo das armas portáteis e da artilharia. Um aspecto da visita de Mitterrand, contudo, embora claramente fundamental, passou despercebido: a data. Por que o presidente da França escolhera aquele dia específico para ir a Sarajevo? Porque 28 de junho era o aniversário do assassinato, em Sarajevo, em 1914, do arquiduque Francisco Ferdinando da Áustria-Hungria, ato que em poucas semanas levou à eclosão da Primeira Guerra Mundial. Para qualquer europeu culto da geração de Mitterrand, saltava aos olhos a ligação entre data e lugar e a evocação de uma catástrofe histórica precipitada por um erro político e de cálculo. Que melhor maneira de dramatizar as implicações potenciais da crise bósnia que escolhendo uma data assim tão simbólica? Mas quase ninguém captou a alusão, exceto uns poucos historiadores
} 
Benjamin define a semelhança (Ähnlichkeit) como o órganon da experiência (Erfahrung $)^{42}$, compreendida, aqui, em seu sentido lato, enquanto experiência substantiva de vida humana. Na Doutrina das Semelhanças, ele observa:

"Sabe-se que o círculo existencial regido pela lei da semelhança era outrora muito mais vasto. Era o domínio do micro e do macrocosmos, para mencionar apenas uma entre muitas realizações que a experiência da semelhança encontrou no decorrer da história. Mesmo para os homens dos nossos dias pode-se afirmar que os episódios cotidianos em que eles percebem conscientemente as semelhanças são apenas uma pequena fração dos inúmeros casos em que a semelhança os determina, sem que eles tenham disso consciência. As semelhanças percebidas conscientemente - por exemplo, nos rostos - em comparação com as incontáveis semelhanças das quais não temos consciência, ou que não são percebidas de todo, são como a pequena ponta do iceberg, visível na superfície do mar, em comparação com a poderosa massa submarina. [T] Mas essas correspondências naturais somente assumem sua significação decisiva quando levamos em conta que fundamentalmente todas elas estimulam e despertam a faculdade mimética que lhes corresponde no homem" ${ }^{\text {"43. }}$.

É igualmente na experiência da semelhança que a experiência da rememoração encontra o seu órganon, quer dizer, o meio pelo qual ela se realiza. É a partir da percepção das semelhanças, das correspondências, dos nexos entre os fenômenos presentes e os eventos de um passado determinado que o processo de rememoração é ocasionado. Tais semelhanças são a expressão da trama do passado no tecido do presente ${ }^{44}$; são a forma de aparição dos acontecimentos do ontem citados nos acontecimentos do hoje; são o modo de manifestação das mais atuais imagens do passado, imagens que estão em correlação direta com as inúmeras questões, buscas, impasses, necessidades, desenvolvimentos e inquietações coletivas do tempo presente.

Ao perceber, no devir de sua própria época, semelhanças que, através da rememoração, lhe remetem aos processos históricos de uma época pregressa, o historiador materialista sente-se visado. Ele sente que as imagens do passado, em sua similitude atual e toda similitude histórica comporta não apenas aproximações, mas especificidades e diferenças -, têm algo de relevante a lhe dizer; algo que é valioso para a compreensão e para

profissionais e cidadãos muito idosos. A memória histórica já não estava viva”. HOBSBAWM, Eric. Era dos Extremos: o breve século XX (1914-1991). $2^{\text {a }}$ ed. São Paulo: Companhia das Letras, 1998, pp. 12-13.

${ }^{42}$ Cf. Passagens, p. 952 ; Passages, p. 863; Passagen, GS, V-2, p. 1038.

${ }^{43}$ BENJAMIN, Walter. "A doutrina das semelhanças". In: 109. Tradução de Sérgio Paulo Rouanet. Cf. GS, II-1, p. 205.

${ }^{44}$ Cf. BENJAMIN, Walter. "Historia e Coleccionismo: Eduard Fuchs". In: . Magia e Técnica, Arte e Política, pp. 108-

I. Prólogo, tradução e notas de Jesus Aguirre. Madrid: Taurus, 1973, p. 104. Cf. GS, II-2, p. 479. 
a transformação do seu próprio tempo histórico. Noutros termos, ao apreender as semelhanças que lhe ensejam o rememorar, o materialista histórico estabelece uma relação substantiva, viva, intensa e consequiente entre o agora (das Jetzt) e o ocorrido (das Gewesene), uma relação carregada de possibilidades de futuros que não vingaram no passado, mas que têm uma significação decisiva para o presente, na medida em que podem nutrir, pela força da crítica, as iniciativas políticas voltadas para a interrupção do continuum da dominação, do mau infinito da acumulação capitalista. Essa interrupção é uma “imobilização [Stillstellung] messiânica do acontecer", "uma chance revolucionária na luta a favor do passado oprimido" 45 , quer dizer, de um passado descontínuo, incompleto e inacabado que não chegou a se sedimentar nos solos pedregosos e cheios de desníveis da realidade histórica.

"O dom de atear ao passado a centelha da esperança pertence somente àquele historiador que está perpassado pela convicção de que também os mortos não estarão seguros diante do inimigo, se ele for vitorioso. E esse inimigo não tem cessado de vencer" ${ }^{\natural 6}$.

“(...) o inferno não é algo que nos espera, mas esta vida aqui”. "Que ‘as coisas continuem assim': eis a catástrofe" ${ }^{47}$.

Em outras palavras, ao distinguir, no vir a ser dos eventos correntes, citações de eventos sucedidos, o historiador materialista "apreende a constelação em que sua própria época entrou com uma determinada época anterior. Ele fundamenta, assim, um conceito de presente como tempo-de-agora, no qual estão incrustados estilhaços do [tempo] messiânico"48 . Isto é, tal historiador instaura um conceito messiânico do presente em que os mais atuais aspectos do passado estão em correlação direta com aspectos específicos da atualidade presente; em que elementos, habitualmente, diacrônicos tornam-se sincrônicos. Um tempo, enfim, "carregado de 'agoras",,49.

O tempo-de-agora (Jetztzeit) é a temporalidade na qual se dá a produção do conhecimento histórico. E, por isso, Benjamin também o denomina de agora da cognoscibilidade (Jetzt der Erkennbarkeit). Nas teses Sobre o conceito de história, ele é

\footnotetext{
${ }^{45}$ Teses, p. 130. Cf. GS, I-2, p. 703.

${ }^{46}$ Teses, p. 65. Cf. GS, I-2, p. 695.

${ }^{47}$ Cf. Passages, p. 491; Passagens, p. 515; Arcades, p. 473; Pasajes, p. 146; Passagen, GS, V-1, p. 592.

${ }^{48}$ Cf. Teses, p. 140; GS, I-2, p. 704.

49 BENJAMIN, Walter. "Sobre o conceito de história". In: Tradução de Sérgio Paulo Rouanet. Cf. Teses, p. 119; GS, I-2, p. 701.
} 
pensado como o conceito de um presente que define exatamente aquele presente em que o materialista histórico escreve a história; ou seja, ele é o lugar em que a "história é objeto de uma construção" ${ }^{50}$.

Mas objeto de uma construção na qual está implicada, como vimos, uma vontade de destruição de tudo o que constitui obstáculo para a realização da felicidade social; vontade de destruição tanto da moderna sociedade produtora de mercadorias quanto das representações históricas que a legitimam. Ele abarca, portanto, os momentos de construção salvadora e de destruição redentora da concepção benjaminiana da história, isto é, da história concebida como ciência e como forma de rememoração. Ou, dito ainda de um outro modo, da historiografia como salvação e conservação dos aspectos soterrados do passado e como atividade crítico-redentora que converge para os esforços políticos de dissolução da ordem social que se expande e se reproduz, aprofundando a exclusão e o sofrimento, no presente. Daí porque sua concepção repousa inteiramente sobre a imagem da redenção. No tempo-deagora, "cada segundo [é] a porta estreita pela qual [pode] entrar o Messias" ${ }^{, 51}$ : passado, presente e possibilidades redentoras de futuro coincidem, condensando-se em diferencial. Ele é a concepção plena e autêntica do verdadeiro tempo histórico, do tempo da verdade enquanto "modelo do [tempo] messiânico"

Trata-se, portanto, de um conceito qualitativo de tempo no qual se edifica um conhecimento histórico concreto e determinado, um agora da cognoscibilidade que se constitui na contramão das representações épicas e conformistas da história e em oposição ao tempo quantitativo, abstrato e homogêneo da exploração e acumulação capitalistas. O que significa dizer que o tempo-de-agora configura um segmento temporal, um diferencial de tempo (Zeitdifferential) destacado da temporalidade ordinária do curso habitual da vida moderna, ritmada pelos ponteiros dos relógios, pelo "tempo infernal em que transcorre a existência daqueles a quem nunca é permitido concluir o que foi começado" ${ }^{\text {,53 }}$. Na modernidade, não dispomos do tempo necessário para "viver os verdadeiros dramas da existência que nos é destinada. (...) As rugas e dobras do rosto são as inscrições deixadas

\footnotetext{
${ }^{50}$ Teses, p. 119. Cf. GS, I-2, p. 701.

${ }^{51}$ Teses, p. 142. Cf. GS, I-2, p. 704.

${ }^{52}$ Cf. Teses, p. 138; GS, I-2, p. 703.

${ }^{53}$ BENJAMIN, Walter. "Sobre alguns temas em Baudelaire". In: Charles Baudelaire: Um lírico no auge do capitalismo. Tradução de José Carlos Martins Barbosa e Hemerson Alves Baptista. São Paulo: Brasiliense, 1989, p. 129. Cf. GS, I-2, p. 635.
} 
pelas grandes paixões, pelos vícios, pelas intuições que nos falaram, sem que nada percebêssemos, porque nós, os proprietários, não estávamos em casa"54.

$$
\begin{aligned}
& \text { “Qui le croirait! On dit qu'irrités contre l'heure } \\
& \text { De nouveaux Josués, au pied de chaque tour, } \\
& \text { Tiraient sur les cadrans pour arrêter le jour",55. }
\end{aligned}
$$

Enquanto dimensão temporal que se afirma em oposição à dinâmica vertiginosa, alienante, ininterrupta e extenuante - para não dizer vampiresca - de tal tempo infernal, o tempo-de-agora também define o "conceito de um presente que não é transição, mas no qual o tempo estanca e ficou imóvel (Stillstand)" ${ }^{, 56}$. Imobilização que consagra o conhecimento histórico aí construído como um agora da cognoscibilidade eminentemente crítico e virtualmente subversor cuja finalidade é tanto salvar o acontecido quanto exercer um efeito redentor no acontecer. Pois "na realidade, não há um só instante que não carregue consigo a sua chance revolucionária - ela precisa apenas ser definida como uma chance específica, ou seja, como chance de uma solução inteiramente nova em face de uma tarefa inteiramente nova. Para o pensador revolucionário, a chance revolucionária própria de cada instante histórico se confirma a partir da situação política. Mas ela se lhe confirma não menos pelo poder-chave desse instante sobre um compartimento inteiramente determinado, até então fechado, do passado. A entrada nesse compartimento coincide estritamente com a ação política; e é por essa entrada que a ação política, por mais aniquiladora que seja, pode ser reconhecida como messiânica. (A sociedade sem classes não é a meta final do progresso na história, mas, sim, sua interrupção, tantas vezes malograda, finalmente efetuada.) "57

Interrupção (Unterbrechung), pois, protagonizada por aqueles novos Josués que, semelhantemente ao veterotestamentário, tomados estarão pelo desejo messiânico de deter o curso do mundo ${ }^{58}$, e de, numa condensação kairológica suprema de toda a história da humanidade, instaurar o instante do novo que começará a ser: o mundo messiânico da atualidade multifacetada e integral. Nele e somente nele, haverá história universal, a ser cumprida não como história escrita, mas como arcaica festa, purificada de toda a

\footnotetext{
${ }^{54}$ BENJAMIN, Walter. "A imagem de Proust". In: de Sérgio Paulo Rouanet. Cf. GS, II-1, pp. 320-321 . Magia e Técnica, Arte e Política, p. 46. Tradução

${ }^{55}$ Teses, p. 123. Cf. GS, I-2, p. 702.

${ }^{56}$ Teses, p. 128. Cf. GS, I-2, p. 702.

${ }^{57}$ Teses, p. 134. Cf. GS, I-3, p. 1231.

${ }^{58}$ BENJAMIN, Walter. "Parque Central". In: Charles Baudelaire, p. 160. Cf. GS, I-2, p. 667.
} 
solenidade ${ }^{59}$ : "Só à humanidade redimida cabe o passado em sua inteireza. Isso quer dizer: só à humanidade redimida o seu passado tornou-se citável em cada um dos seus instantes. Cada um dos instantes vividos por ela torna-se uma citation à l'ordre du jour - dia que é justamente, o do Juízo Final"60.

\footnotetext{
${ }^{59}$ Cf. BENJAMIN, Walter. "Apuntes sobre el concepto de historia". In: La Dialéctica en Suspenso, p. 86; BENJAMIN, Walter. "Paralipomènes et variantes des Thèses Sur le concept d'histoire". In: Écrits Français, p. 355 ; GS, I-3, p. 1238.

${ }^{60}$ Teses, p. 54. Cf. GS, I-2, p. 694.
} 